\title{
Chemical arms exports embarrass Bonn
}

\section{Bonn}

ON 11 January, as West Germany and 148 other nations resolved at a Paris conference to eliminate chemical arms worldwide, the first hard evidence began to appear linking West German companies to the alleged Libyan chemical weapons factory at Rabta. By now, as many as 30 firms have been implicated, although the West German government still insists that it has not seen evidence "admissible in a court of law." One day earlier, West Germany had announced new measures to restrict exports of "sensitive" goods of a military, nuclear or chemical nature. The restrictions came in response to a December scandal in which at least two West German firms are suspected of having delivered nuclear technology to Pakistan, India and South Africa in possible violation of the nuclear non-proliferation treaty.

The revelations about West German participation in the Rabta plant embarrassed the Bonn government. West Germany had been under pressure from the United States to investigate exports to Libya by Imhausen-Chemie $\mathrm{GmbH}$, a company based in the Black Forest. A first investigation by tax authorities in Freiburg in early January cleared the firm.

Chancellor Helmut Kohl refuted the US charge, saying on 10 January that the United States had "put the Germans in the dock without giving us a chance to see the evidence." The next day, the news magazine Stern broke the news that the West German customs service had evidence against Imhausen and other firms. At the end of the week, the government revealed that the Federal Intelligence Service (Bundesnachrichtendienst) had informed Kohl in October that Imhausen might have violated export laws. The public prosecutor's office in Offenburg has begun a new investigation.

Regulating exports has always been a sensitive matter for West Germany, whose annual exports are worth more than DM 500,000 million. The new regulations put tighter controls on the export of technology and know-how in the nuclear, chemical and munitions areas. The government also recommends increasing the penalties for breaking export laws. The maximum prison term will be raised from three years to five years and the maximum fine from DM 500,000 to DM 1 million.

The government hopes to restrict future arrangements like the alleged ImhausenLibya deal by lengthening the list of "sensitive areas," which previously included only the Soviet bloc and countries at war. Furthermore, the government recommends prosecuting Germans overseas found to have a hand in the production of chemical or biological weapons.
The opposition criticized the government measures while calling for a parliamentary investigation of the "poison gas affair" as it is coming to be called. Bundestag (parliament) member Norbert Wieczorek (Social Democrat) said it was hypocritical of the government to oppose exports which could lead to chemical arms production only when they go outside the European Community (EC). Wieczorek said that "there are not enough teeth" in the new regulations. He said that the fines discussed were "ridiculous sums" which would be considered by violators as just another operating cost.

Wieczorek admits that tougher controls do not guarantee that undesirable exports will stop. The volume of exports is so great, and the customs and regulatory authorities so understaffed, that many products will continue to pass through undetected. Only by increasing the penalties and the number of spotchecks will

would-be violators be discouraged.

Perhaps the thorniest part of the problem comes in the area of "dual-use" technologies, such as the pesticide factory built at Samarra, Iraq, with the help of West German companies. It is has now been established that the factories produced poison gas, which Iraq apparently used during its 8-year war with Iran and on its own Kurdish population. But the guilt of the West German firms remains in doubt because it is unclear if they knew how their products would be used. An investigation into the matter is in its fifth year.

Another firm, Karl Kolb AG of Dreieich, has avoided prosecution under the current export laws by challenging the laws in court. Kolb was one of the companies charged with delivering equipment for the pesticide factory to Iraq. Kolb won the first court case; the government is now appealing.

Steven Dickman

\section{Some good news some bad from Paris}

\section{Paris}

THE five-day Paris conference on chemical weapons closed on 11 January with all 149 participating nations declaring their readiness to "prevent all recourse to chemical arms, by eliminating them completely". But the declaration has already been criticized as not going far enough.

Britain, for example, would have liked concrete measures to prevent the proliferation of chemical weapons and an international commitment to punish governments that used them.

The declaration should, however, speed progress at the Geneva disarmament conference, whose 40-nation membership is trying to formulate a legally binding decree to ban the production and stockpiling of chemical weapons. The declaration asks the Geneva conference to redouble its efforts "urgently to resolve remaining problems" and to draw up a convention.

The plenary committee set up to draft the declaration had to compromise after heated exchanges among the participants. Iran, in particular, wanted Iraq to be pilloried. Syria defended possession of chemical arms so long as Israel has the nuclear bomb. Initial insistence by some other developing nations that there could be no chemical disarmament without nuclear disarmament was eventually dropped. In the final document, individual nations were not named, although the use of chemical weapons in recent wars is condemned.

There was further trouble when the South African foreign minister, Pik Botha, took the platform on 9 January. Many African delegates walked out, as well as one French delegate. But the biggest news from the conference remains the announcement that the Soviet Union will halt production of chemical weapons immediately and will start the ten-year process of destroying its stocks. The Soviet move includes an acceptance that international inspection will be essential to

\section{IMAGE UNAVAILABLE FOR COPYRIGHT REASONS}

Lone voice: Pik Botha spoke but few were there to listen.

make compliance believable. But the view of the outgoing US administration is that the problems surrounding inspection are "insurmountable", given the ease with which conventional factories can be modified to produce chemical weapons.

Despite the obstacles to a complete treaty, the Paris declaration holds promise as a deterrent to further proliferation. The high profile surrounding the Paris meeting has already helped put pressure on nations such as West Germany, accused of supplying technology to Libya for chemical arms manufacture, to re-examine export controls (see above).
Peter Coles 